\title{
Women as vectors of social entrepreneurship
}

\author{
Albert Nsom Kimbu ${ }^{\mathrm{a}, *}$, Michael Zisuh Ngoasong ${ }^{\mathrm{b}}$ \\ a University of Surrey, United Kingdom \\ ${ }^{\mathrm{b}}$ The Open University, United Kingdom
}

\section{A R T I C L E I N F O}

\section{Article history:}

Received 6 November 2015

Revised 16 June 2016

Accepted 25 June 2016

\section{Coordinating Editor: Robin Nunkoo}

\section{Keywords:}

Social entrepreneurship

Women social entrepreneurs

Social transformation

Communities in need

Institutional context

\begin{abstract}
A B S T R A C T
Drawing on the literature examining women in the tourism sector and social entrepreneurship, this article critically explores a theoretical framework for analyzing the role of women ownermanagers of small tourism firms (STFs) as social entrepreneurs. Through a qualitative analysis of owner-managers of STFs, the article provides evidence of how women integrate social transformational and commercial goals in their business strategies, while serving defined communities around the tourism sector. By critically examining the operationalization of these goals and community needs, the development impacts of women-owned STFs and opportunities for women social entrepreneurship in the tourism sector are identified and discussed.
\end{abstract}

Crown Copyright $\odot 2016$ Published by Elsevier Ltd. All rights reserved.

\section{Introduction}

This article critically explores a model of social entrepreneurship focusing on the nature of engagement and participation by women entrepreneurs in tourism. Research on social entrepreneurship defined as "entrepreneurial activity with an embedded social purpose" (Austin, Stevenson, \& Wei-Skillern, 2006, p.2) has grown in the last decade (Christoph, Laeis, \& Lemke, 2016; Kline, Shah, \& Rubright, 2014; Mair \& Marti, 2006; Von der Weppen \& Cochrane, 2012; Zahra, Gedajlovic, Neubaum, \& Shulman, 2009). Studies on social ventures in developed and developing economies suggests that social entrepreneurship is a key contributor to the creation and diversification of

\footnotetext{
* Corresponding author.

E-mail addresses: a.kimbu@surrey.ac.uk (A.N. Kimbu), michael.ngoasong@open.ac.uk (M.Z. Ngoasong).
} 
entrepreneurial activity, economic growth, emancipation and empowerment of women (Datta \& Gailey, 2012). Limited research in the tourism sector in African destinations highlights successful female entrepreneurial activities (Kwaramba, Lovetta, Louwb, \& Chipumuroc, 2012). However, entrepreneurship development studies suggest that more research is needed to understand how women who engage in social entrepreneurial activities support local development in the face of community traditions and social norms (Amine \& Staub, 2009; Huysentruyt, 2014).

The focus on development is significant because tourism entrepreneurship has been identified as a potential vehicle for women empowerment (Kwaramba et al., 2012; Peeters \& Ateljevic, 2009), for increasing gender equality (UNWTO, 2011) with economic and social benefits, especially in maledominated emerging destinations (Acharya \& Halpenny, 2014). Enterprises that pursue commercial approaches to achieving social and/or environmental aims are increasing in tourism with many expressing responsible tourism through contributing to poverty alleviation and environmental protection (Von der Weppen \& Cochrane, 2012). With Africa's tourism sector experiencing the second fastest growth rate in the world (UNWTO, 2015), the role of women as social entrepreneurs through tourism can have particularly strong developmental impacts in this region. Although the role of women as social entrepreneurs is increasingly attracting attention (Datta \& Gailey, 2012), there is a dearth of research on women social entrepreneurs in tourism in general and emerging destinations in particular. From this context, the study explores the following two research questions:

1. In what ways can women owner-managers of STFs in emerging destinations be considered as social entrepreneurs?

2. How do women overcome existing barriers to female participation in local development around tourism?

By answering the above questions this article provides two contributions to tourism social science research. First we integrate the theoretical lens of social entrepreneurship and the literature on women in tourism to critically analyze the role of women as vectors of social entrepreneurship in tourism. They are social entrepreneurs because they simultaneously pursue commercial and social goals (Ruebottom, 2013) by taking risks and making do of whatever resources they can access to fill a market need and contribute to local development (Di Domenico, Haugh, \& Tracey, 2010) around the tourism sector or destination (Kline et al., 2014). Based on the empirical analysis we develop a theoretical framework depicting the role of women-owner managers of STFs in terms of the combination of commercial/economic goals they pursue, the social transformation that they seek to create in society and the associated impacts on the specific communities they serve (Di Domenico et al., 2010; Ruebottom, 2013; Zahra et al., 2009). This framework can be applied to analyze the circumstances under which women can be considered as social entrepreneurs and their associated impacts on local development around tourism. This significant contribution which has barely been explored, complements extant tourism research which emphasizes the economic benefits, opportunities and challenges associated with women-owned STFs in emerging destinations (Acharya \& Halpenny, 2014; Desa, Johnson, \& Ergul, 2012; Kline et al., 2014; Kwaramba et al., 2012).

Secondly, in studying women owner-managers of STFs in Cameroon, we complement the limited previous research (e.g. Von der Weppen \& Cochrane, 2012) by uncovering how women as social entrepreneurs in an emerging destination, use their STFs as platforms to promote local development through training, employment/job creation, and poverty alleviation around tourism. Existing tourism social science research has focused on women as workers and their role in the tourism workforce, arguing that such roles have enabled women to create 'new' self-identities by securing economic and social independence in ways that impact other community members (Cone, 1995; Duffy, Kline, Mowatt, \& Chancellor, 2015; Gentry, 2007). Though providing good prima facie understanding of the role of women in developments around tourism, little is known about the wider impacts of women involvement in the tourism sector beyond business creation for economic benefits (Acharya \& Halpenny, 2014; Kwaramba et al., 2012).

To address the above gaps, we use Cameroon to empirically analyze the role of women as social entrepreneurs in emerging destinations that are under-researched (Kimbu \& Ngoasong, 2013). We adopt a qualitative approach based on focus groups (Buzinde, Kalavar, Kohli, \& Manuel-Navarrete, 
2014), complemented by survey questionnaires (Newby, Soutar, \& Watson, 2003) and rapid participant observation (Mitas, Yarnal, \& Chick, 2012; Ngoasong \& Kimbu, 2016). A country-specific focus on one destination and a niche area (women as social entrepreneurs) responds to calls for research to study entrepreneurial behaviors, both social and commercial, within its local context (Welter, 2011). Context here refers to the tourism sector and institutional settings (formal laws/regulations and informal relationships), which impose contextual influences, such as entry and post-entry behaviors and actions on entrepreneurs (Ngoasong \& Kimbu, 2016; Welter, 2011).

The next section develops a theoretical framework for analyzing the role of women ownermanagers of STFs as social entrepreneurs in Cameroon. This is followed by a description of the study methods, results and discussion respectively. Finally, conclusions and future research opportunities are presented.

\section{Literature review}

Women as owner-managers of small tourism firms

Existing research on tourism in developing countries documents the significance of women in emerging destinations as workers, members of the workforce (Duffy et al., 2015; Gentry, 2007; Moswete \& Lacey, 2015), and owner-managers of STFs (Acharya \& Halpenny, 2014). STFs include small hotels, B\&Bs, snack bars, restaurants, catering services, events planning/management, tour operator/ guide, transport services, arts \& craft and souvenir vendors (Akehurst, Simarro, \& Mas-Tur, 2012; Desa et al., 2012). The evidence demonstrates how the tourism sector provides employment to women and potentially enhances their economic and social independence. To realize independence as workers, women have to negotiate workloads and domestic tasks with their husbands, which leads to an extension of their traditional gender roles and identities (Duffy et al., 2015; Gentry, 2007). Cone (1995) noted that as owner-managers of art \& craft businesses, women are thrust into the public spheres and market systems leading them to create 'new' self-identities with wider impacts on their communities. The new identities and the associated impacts on local communities in emerging destinations as a result of women owning and managing STFs provide two rationales for this research.

Firstly, although previous research acknowledges women as owner-managers that are capable of creating and operating STFs (Akehurst et al., 2012), even in male-dominated developing country destinations (Acharya \& Halpenny, 2014; Derera, Chitakunye, \& O'Neill, 2014); the wider development impacts of women-owned STFs, and the extent to which these form part of their enterprise creation intentions, have received very limited attention in the tourism development literature. In the case of African countries, the focus of this article, insufficient venture financing means that womenowned businesses are mostly in the retail and service industry, with entrepreneurship being a simple extension of their hobbies that are frequently related to their domestic roles (Derera et al., 2014). Research has also examined how state-led development projects assist disadvantaged women to become self-reliant owners of homestay businesses (Kwaramba et al., 2012). Despite such evidence of the changing status of women, we know little about the wider development impact that women have on the tourism sector in these countries.

Secondly, the focus of this research specifically on women responds to recent calls for the tourism sector to create wider development impacts beyond the sector (Ngoasong \& Kimbu, 2016). According to Amine and Staub (2009) encouraging more women entrepreneurs is both socially and economically desirable and promotes development through increased employment and economic activity. They identify many obstacles to be overcome in the process, such as: local socio-cultural norms and traditions, education of the women and girl child, country legislation and implementation on gender equality. Studies of women entrepreneurs who have overcome these obstacles to create new business opportunities in Africa (World Bank, 2008) and beyond suggest the case for such women to be considered as social entrepreneurs due to the societal value they create through the use of own revenues (Huysentruyt, 2014). Tourism literature recognizes this societal value in terms of poverty alleviation, environmental protection, and shaping the tourism destination landscape (Kline et al., 2014; Von der Weppen \& Cochrane, 2012). However, there is a relative neglect of the role of women owner-managers 
in transforming the tourism sector and the associated societal impacts. The next section develops a theoretical framework for analyzing the circumstances under which women owner-managers of STFs can be considered as social entrepreneurs and how they use their businesses as platforms for social transformation and local development.

\section{Theoretical framework}

We draw on the literature on social entrepreneurship to develop a framework for analyzing the role of women as social entrepreneurs. Social entrepreneurship "involves seizing opportunity for the market-changing innovation of a social purpose" (Luke \& Chu, 2013, p. 765). This social purpose can be achieved by creating and operating either a non-profit or a for-profit venture. Unsurprisingly, the term 'social enterprise' and 'social entrepreneurship' are often used interchangeably despite the fact that "not every enterprise is entrepreneurial" (Luke \& Chu, 2013, p. 764). To understand the role of women as social entrepreneurs we focus on the notion of a "heroic individual social entrepreneur" (Short, Moss, \& Lumpkin, 2009, p. 181) and the survival or otherwise of her social entrepreneurial venture (Mair \& Marti, 2006; Zahra et al., 2009) rather than on collective and community effort to launch a social enterprise (Datta \& Gailey, 2012). In particular, we focus on the role of the woman as ownermanager of a small tourism firm (STF), which may involve some collective or community enterprise activities (Ngoasong \& Kimbu, 2016), i.e. women as individuals with self-identities. In-depth coverage of cooperative social enterprises, and gender differences (Gibson, 2009) is therefore beyond the scope of this research (Nikina, Shelton, \& LeLoarne, 2015).

Social entrepreneurs are similar to commercial entrepreneurs in terms of identifying and pursuing opportunities, creating and operating new ventures and satisfying customer needs/demands (Nikina et al., 2015; Short et al., 2009). However, it is the conscious objectives and the embedded social purpose that reveals the nature of social entrepreneurship that is being pursued (Austin et al., 2006). Social ventures pursue both economic/profit and social goals simultaneously (Mair \& Marti, 2006; Zahra et al., 2009). They can be categorized in terms of: (1) a not-for-profit venture that undertakes commercial activities to generate revenue that will enable it to sustain its operations; (2) a forprofit venture that has an explicit mission to pursue both social and economic objectives or (3) a hybrid venture that combines both not-for-profit and for-profit motives. In the absence of a universally agreed academic and legal definition of a social enterprise (Desa, 2012; Teasdale, Lyon, \& Baldock, 2013) this broad categorization is consistent with established arguments to include the full range of enterprises from "non-governmental organizations with few earned-income options to forprofit startup ventures with a social mission" when studying social enterprises in Latin America, Asia, and Africa (Desa, 2012, p. 729).

Through an examination of ten for-profit and not-for-profit social enterprises, Ruebottom (2013) suggests two criteria for judging legitimate social entrepreneurs: (1) that a social transformation goal is intrinsic to their mission (e.g. environmental protection) and (2) the enterprise serves a community in need (e.g. a for-profit-restaurant that trains and employs street youths as chefs and waiting staff thereby serving social service agencies and the local restaurant industry). Applying this thinking to women owner-managers of STFs includes looking at their motivations, the various actions and processes that they follow to discover and exploit opportunities locally, which defines them as bricoleurs (Zahra et al., 2009). Baker and Nelson (2005) describe a bricoleur as an entrepreneur who makes do by combining and recombining whatever resources are available to solve problems; where resources include "physical artifacts, skills, or ideas that are accumulated" that may "come in handy" (p. 336). A focus on the owner-manager as a bricoleur is significant where the aim is to identify "less rational types of entrepreneurial behaviors" (Stinchfield, Nelson, \& Wood, 2013, p. 893), traditional definitions of resource acquisition and social resourcing and relational assets that help social entrepreneurs to deal with bootstrapping (Di Domenico et al., 2010).

In an analysis of owner-managers of small firms in resource-constrained settings, Baker and Nelson (2005) found that bricolage can lead to either positive, negative or neutral outcomes/consequences. However, it is beyond the scope of this study to evaluate the impact of bricolage and the actions of a bricoleur. The aim is to critically examine how the actions and processes used by women to create STFs reveals their motivation to engage in social transformation of their self-identities, with wider 
impacts on 'others' within their local communities (Cone, 1995) and the tourism sector in general. Transforming 'others' includes providing employment, income and improved livelihoods to poor and marginalized persons beyond the immediate family of the social entrepreneur (Ruebottom, 2013). For most women in emerging destinations, commercial goals range from the bare survival of their enterprises, to the additional income generated to supplement personal and household income and any additional profits that may accrue, all of which shape their motivation to create social enterprises (Datta \& Gailey, 2012; Derera et al., 2014). This means that understanding their motivation, goals, and persistence has to take into account the combination of financial and non-financial factors, both of which are equally important in how the entrepreneurs would define intentional and desirable success and performance (Stinchfield et al., 2013).

Restaurants (Ruebottom, 2013), accommodation providers and trekking/cycling tour operators have been studied to illustrate how social entrepreneurs serve the needs of the tourism sector (Von der Weppen \& Cochrane, 2012). The evidence from these studies suggests a focus on the needs of the woman entrepreneur as the 'self' (Cone, 1995), marginalized persons/ communities (the poor), and tourists (affluent) as the 'others' (Cave, 2005). Addressing these needs reflects calls for the tourism sector to promote local development in emerging destinations through locally-owned STFs (Ngoasong \& Kimbu, 2016). Research suggests that international tourists prefer tourism services that are owned by outsiders and local elites, and visit attractions from which the poor are excluded leading to economic leakage and demonstration effects (Gibson, 2009). Many resorts in emerging destinations discourage the poor and this reduces their chances to engage with tourists (Harrison, 2008). Thus, deliberate attempts by women-owned STFs to serve these tourist communities can be considered as a social transformational goal. There are also opportunities to serve diaspora tourists who visit their emerging destination home countries and have preference for locally provided services (Cave \& Koloto, 2015).

From the above theoretical position, women who identify and pursue entrepreneurial opportunities by successfully creating and operating STFs that serve defined needs of the tourism sector can be studied to understand the extent to which they can be considered as social entrepreneurs. It is on this basis that we critically examine the role of women as vectors of social entrepreneurship in tourism.

\section{Research context and methods}

\section{The context of women owner-managers of small tourism firms in Cameroon}

Our research setting is Cameroon, an emerging but under-researched destination (Kimbu \& Ngoasong, 2013) with an institutional context (Welter, 2011) that creates opportunities, but poses many challenges and risks for female social entrepreneurs (Epo, 2012). We focus on four towns/ regions for their similar and contrasting tourism features (Kimbu \& Ngoasong, 2013; Ngoasong \& Kimbu, 2016). Firstly, the South West Region, renowned for ecotourism, black sandy beaches, botanical and zoological gardens in Victoria, mountaineering and hiking expeditions around Mount Cameroon and colonial architecture and historical sites in Buea. Consequently, many small travel agents and tour guides operate in this region. Secondly, Bamenda (North West Region) is famous for cultural and heritage tourism and served by hundreds of artisans, carvers and blacksmiths. The above mentioned towns/regions are semi-urban agglomerations. Thirdly Douala (Littoral Region) and lastly Yaoundé (Centre Region), Cameroon's economic and political capitals respectively are urban agglomerations, and internationally-renowned for MICE tourism (Meetings, Incentives, Conventions and Exhibitions) in the Central African sub-region (Fig. 1). This is a growing market for catering, events management, and travel and tour agents. In addition to the above, accommodation and food/beverage providers can be found in all four towns/regions. The focus on different town/regions reflects sub-national coverage and includes the full range of the types of STFs in Cameroon's tourism sector.

In terms of institutional context, regulations on business registration, financing, labor, taxes and property rights arguably have equal provisions for men and women (Stevenson \& St-Onge, 2011; World Bank, 2008). However, women are known to suffer from sexual harassment and intimidation 


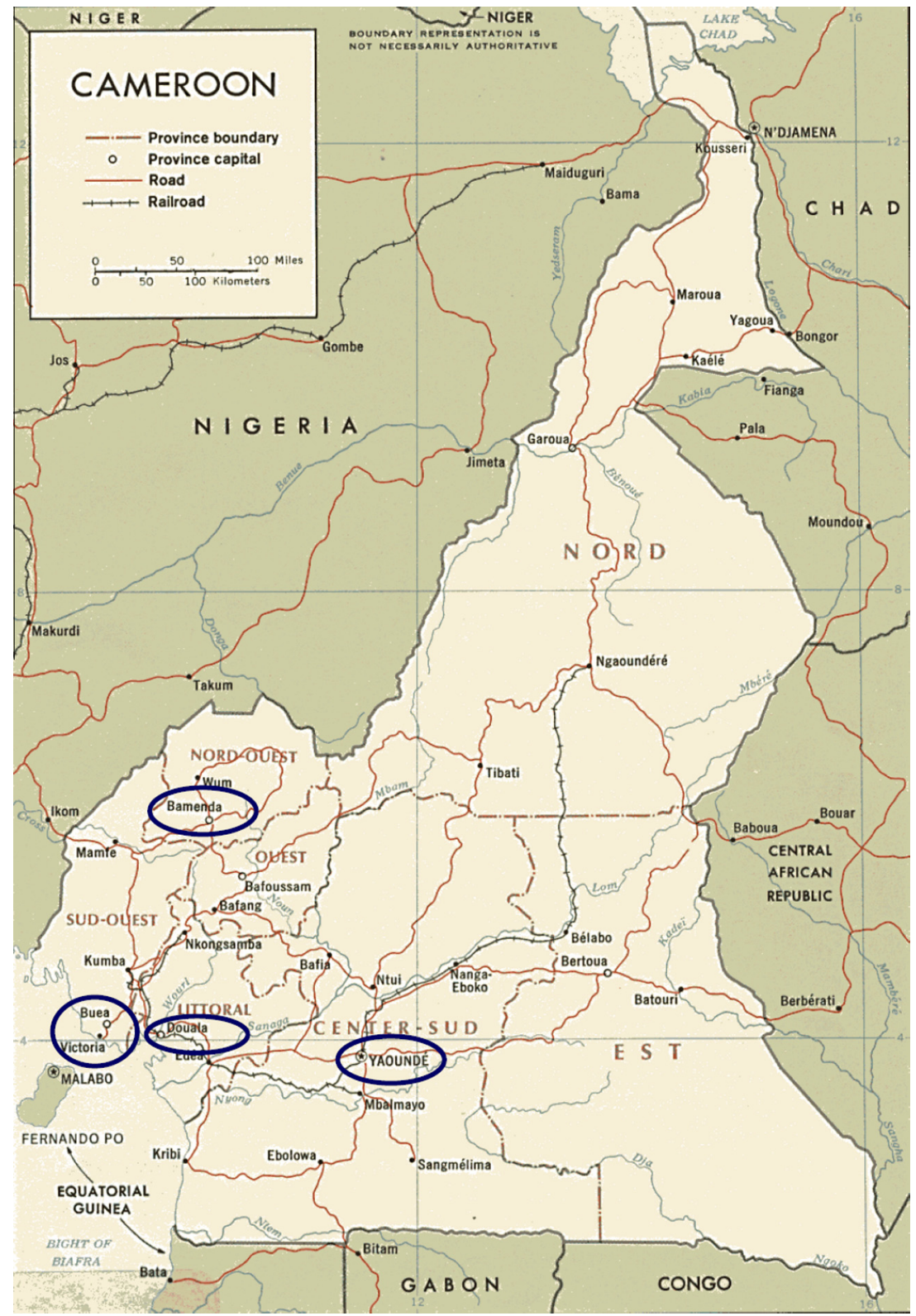

Fig. 1. Map of Cameroon indicating study sites.

while ethnic/traditional practices prevent them from owning property (Stevenson \& St-Onge, 2011) and creating businesses (World Bank, 2008). Nevertheless, an increasing number of women are overcoming these barriers and becoming entrepreneurs with similarly proven entrepreneurial and managerial rigor as men (Stevenson \& St-Onge, 2011). They rely on informal self-organizing cooperatives/associations and family networks to secure resources and legitimacy, thereby operating smaller and sometimes informal (unregistered) businesses (Epo, 2012; Stevenson \& St-Onge, 2011). 
The informality implies that the social transformation and commercial goals and the communities they serve are not as documented as those in advanced destinations (e.g. Ruebottom, 2013). While some businesses register as limited companies, Common Initiative Groups and cooperatives, others operate in the informal sector (Ngoasong \& Kimbu, 2016). It is therefore through detailed sectorspecific qualitative studies that their transformative roles can be documented and enhanced.

\section{Research design and sampling}

While there is some research on women and entrepreneurship in Cameroon (e. g. Epo, 2012; Stevenson \& St-Onge, 2011), there is limited published literature on women as social entrepreneurs in Cameroon. We adopted an exploratory research design, involving the complementary use of questionnaires, focus groups and rapid participant observation. This approach is highly regarded as suitable for studying small businesses and entrepreneurs (Newby et al., 2003; Ngoasong \& Kimbu, 2016) and for "eliciting the opinions, perceptions and experiences in interactional" tourism milieus (Buzinde et al., 2014, p. 6). To ensure that our research approach and findings are open to external appraisals and transferability we used purposive sampling to select study participants (Bernard, 2012; Ngoasong \& Kimbu, 2016).

The selection of study participants was informed by three criteria. First, geographic sampling ensured selection of a range of region-specific STFs across the tourism sector. Second, the institutional context, which is male-dominated and where men have intent in playing active roles in their wife's decision-making (Stevenson \& St-Onge, 2011). Both women and men were therefore recruited with men serving as an indicative control group (Gentry, 2007; Moswete \& Lacey, 2015). Third, to capture different typologies of enterprises, for-profit vs. not-for-profit (Teasdale et al., 2013), formal (stateregulated) vs. informal STFs were selected (Ngoasong \& Kimbu, 2016).

Given concerns about informality and limited publicly available information about potential participants, it was decided that rather than presenting the research objectives and questions in focus groups (e.g. Buzinde et al., 2014), a survey questionnaire should be used both to recruit a useful sample of study participants, collect background socio-demographic and enterprise-specific information (Akehurst et al., 2012; Desa et al., 2012; Epo, 2012; Newby et al., 2003), start generating focus group questions, and engaging participants with the themes to be explored during the focus groups. Furthermore, rapid participant observation, conducted throughout the fieldwork, ensured data checking and corroboration (Mitas et al., 2012).

Two female research assistants, both recent university graduates were hired and trained by the lead author to recruit participants, administer questionnaires and take notes during focus groups. Given that Cameroon is bilingual, the questionnaires were administered in both French and English. A total of 72 questionnaires were completed, 55 were considered usable (10-12 per region), analyzed descriptively (Newby et al., 2003) and the participants invited for the focus groups (Table 1 ). The category labeled as others are tourism related enterprises (e.g. a health clinic in a popular tourist attraction). As suggested in Duffy et al. (2015), understanding women in tourism includes a consideration of tourism, not as an isolated activity, but one that is embedded in a wider socio-cultural and economic context of a destination. This small sample size is justified on grounds of purposive sampling in an emerging destination with fewer tourist numbers by global standards (Kimbu \& Ngoasong, 2013). While this can be a limitation, it is local context-specific (Welter, 2011). Combining questionnaires, focus groups and direct observations ensures in-depth coverage and thick description (Bernard, 2012; Decrop, 2004).

\section{Data collection and analysis}

The fieldwork for the study was conducted through three visits from May 2014 to January 2015, each lasting two weeks. The first visit was used to train the research assistants and administer questionnaires. The second and third visits were devoted to conducting five focus groups and rapid participant observation by the main author and co-author respectively. A small financial incentive was guaranteed to each participant as transport allowance to and from the focus group venue to encourage participation and each signed a consent form, which assured anonymity. Ten participants took part in 
Table 1

Profile of questionnaire respondents.

\begin{tabular}{lll}
\hline Demographic categories & Sub-categories & Number of respondents \\
\hline Age (years) & $18-25$ & 8 \\
& $26-45$ & 41 \\
Education (Highest Qualification) & Above 45 & 6 \\
& Primary School & 2 \\
& Secondary/High School & 23 \\
Family status & University Degree & 22 \\
& Other (e.g. apprenticeship) & 18 \\
Primary source of venture financing & Single/Divorced/Separated & 32 \\
(some raise funds from multiple & Married/Widowed (with Children) & 25 \\
sources) & Personal savings & 35 \\
& Loans from family/friends & 20 \\
Size (No of employees) & Loan from banks & 11 \\
& Grants (government \& external agencies) & 4 \\
Gender & Below 5 & 32 \\
& 6-10 & 17 \\
\hline
\end{tabular}

each focus group, which is consistent with extant literature (Buzinde et al., 2014; Newby et al., 2003) although two participants came late in Focus Group 1 and did not fully participate. To obtain a balanced discussion we varied gender representations in the focus groups, with Focus Group 1 being the control group (Gentry, 2007) (Table 2). The combination of gender-specific and mixed gender focus groups was done to "ensure that a broad cross-section of views and opinions [were] canvassed on the topic of interest" (Newby et al., 2003, p. 422).

English was used in Buea and Bamenda as this was their preferred language, while participants in Yaoundé and Douala agreed to speak either English or French as these metropolitan cities are highly bilingual. The questions asked in both the questionnaires and the focus groups were guided by the literature review. Apart from demographic details (Table 1), the questionnaire contained agree/disagree statements about the motivations/goals, barriers and success criteria for women as owner-managers of STFs on a Likert scale of 1-5 ( 1 = fully disagree, 5 = fully agree) (Akehurst et al., 2012; Newby et al., 2003). This provided initial insights into the themes such as commercial vs. social goals, success as profits vs. social impact, and the major barriers to success. The focus groups then explored these themes in more depth, teasing out illustrative cases from women participants who owned STFs. Each

Table 2

Geographic spread of focus group participants and type of business.

\begin{tabular}{|c|c|c|c|c|c|}
\hline \multirow[t]{2}{*}{ Line of business } & \multicolumn{5}{|c|}{ Number of Participants } \\
\hline & $\begin{array}{l}\text { Buea (FG 1: } \\
\text { Men E'Women) }\end{array}$ & $\begin{array}{l}\text { Bamenda (FG 2: } \\
\text { Women-only) }\end{array}$ & $\begin{array}{l}\text { Douala (FG 3: } \\
\text { Women-only) }\end{array}$ & $\begin{array}{l}\text { Yaoundé (FG 4: } \\
\text { Women-only) }\end{array}$ & $\begin{array}{l}\text { Douala (FG 5: } \\
\text { Men-only) }\end{array}$ \\
\hline Hotels, bed \& breakfast & 2 & 1 & 1 & 1 & 3 \\
\hline $\begin{array}{l}\text { Restaurants, snack bars \& } \\
\text { catering }\end{array}$ & 2 & 2 & 2 & 3 & 1 \\
\hline Decor \& events management & 1 & 2 & 3 & 2 & 1 \\
\hline $\begin{array}{l}\text { Tour operators, guides, \& } \\
\text { transport services }\end{array}$ & 2 & 1 & & 1 & 2 \\
\hline $\begin{array}{l}\text { Arts, craft, curio makers/ } \\
\text { vendors }\end{array}$ & 1 & 2 & 2 & 1 & 1 \\
\hline $\begin{array}{l}\text { Others (Health Clinic, } \\
\text { Microfinance, Women } \\
\text { Association) }\end{array}$ & 2 & 2 & 2 & 2 & 2 \\
\hline Total & 10 & 10 & 10 & 10 & 10 \\
\hline
\end{tabular}


focus group lasted between 70 and 90 mins and was recorded. Rapid participant observation consisted of the research assistants and both authors staying in hotels, eating in restaurants and using travel services owned by participants throughout the fieldwork. Participants' catering and events services prepared the venues and lunches for the focus groups. Observations, informal discussions with staff/ employees and documents (e.g. leaflets, company reports) were recorded as field notes to complement data analysis (Kwaramba et al., 2012).

Descriptive statistics, namely mean scores were used to analyze the questionnaires, with separate analysis for women (main participants) and men (control group) (Gentry, 2007). Such descriptive statistics can be useful to confirm study variables and better inform subsequent focus group discussions (Newby et al., 2003) where the aim is not to analyze the relationships among the variables (Akehurst et al., 2012). The focus group (FG) data was manually transcribed and unique code numbers given to each participant to ensure anonymity. The data was then thematically analyzed (Bernard, 2012) to isolate transformational and commercial goals, community needs served, illustrative cases of STFs, and direct quotations to support the empirical analysis (Ngoasong \& Kimbu, 2016). Only direct quotations from women are provided, with those of men (FG 1, FG 5, and 10 questionnaires) used as indicative (Moswete \& Lacey, 2015) and to triangulate and validate the data (Decrop, 2004). Further triangulation and validation of the data that had been checked by both authors was ensured through informal interviews with two award-wining women social entrepreneurs based in Douala and a renowned female Lawyer based in Yaoundé (e.g. Bruton, Khavul, \& Chavez, 2011). The next section presents our study findings.

\section{Findings}

The results from analyzing the questionnaires, focus groups and rapid participant observation data provide evidence of social transformational and commercial goals of women as social entrepreneurs and owner-managers of micro- and small-tourism firms (STFs). There were no distinctive differences in the quantitative and qualitative responses. Unpacking how the motivation to pursue these goals provide platforms for women to identify and serve defined community needs around tourism forms a basis for discussing the wider development impacts of women owner-managers of STFs.

\section{Women and small tourism firms: Social transformation vs. commercial goals}

To understand the social transformation and commercial goals pursued by women as ownermanagers of STFs, we analyzed the results from both the questionnaires and the focus groups. The results usefully and variably confirm existing research concerning the motivations for women starting STFs and the barriers or challenges that restrict success as women owner-managers of STFs (Desa et al., 2012; Newby et al., 2003). The average questionnaire scores of the responses for both women and men participants were variably consistent and substantiated by the focus group discussions.

In terms of motivation to create a STF, the questionnaire results revealed that contributing something to society (4.2) and professional independence/advancement (3.8) had the highest average scores and therefore seen as most important. Both are related to the social transformation of 'others' and the 'self' respectively as discussed earlier. In the focus groups, contributing something to society (Huysentruyt, 2014) was illustrated by accounts of women owner-managers deliberately employing under-privileged persons and/or using a large proportion of the income from their business to contribute to local development initiatives. One participant described how "when you go to orphanages nowadays, so much support comes from women. If you want to change our society, you help a woman to change her life. Then the woman will change the world" (FG4, P8). Another woman noted that "the rate of prostitution can be reduced if women are enabled to be more creative" (FG3, P2). Accounts of professional independence/advancement were consistent with transformation of the "self (Gentry, 2007), and provided a basis for being able to transform 'others'. The participants spoke along the lines of "being independent and not just sit at home as a housewife who gets everything from her husband" (FG2, P6); and not wanting to "sit idle at home [as housewife] and not pursue my childhood dream to be a decorator" (FG1, P3). 
Income generation/making profit (3.6) and developing business skills (3.6) were the next important factors that motivated the women to create a STFs. These are related to the commercial goals of social entrepreneurs (Ruebottom, 2013; Stinchfield et al., 2013). In the focus groups, supporting illustrative quotes included:

"I wanted to earn better than I did in my previous job and help poor people in our society [through membership in tribal/village associations]" (FG3, P1);

"Looking for a job is not easy. I decided to start a business [restaurant] so as to avoid unemployment and to provide a means to train young girls interested in this type of business" (FG4, P9);

"As a single mum I have to generate income to support my family and not depend on other people" (FG1, P2).

It was observed that even those participants who identified a commercial goal, especially those whose STFs were registered as limited companies, noted how profit maximization only became very important as their enterprises became profitable and started expanding (e.g. Mair \& Marti, 2006). Instead they pointed to the poverty within their immediate and external family and the lack of well-paid full time employment as the key drivers in the early stages of their decision-making. Thus, it is unsurprising that participants did not see the challenge of owning/running a STF (3.3), recognition and social prestige (2.3), and not being happy in their previous job (2.2) as the most important motivations for creating a STF.

In terms of barriers facing women as owner-managers of STFs, difficulty in obtaining financing (3.7), legislation, bureaucracy, taxes (3.5), lack of information (3.4), and managerial/operational challenges of operating a business (3) were ranked highest. As discussed earlier in the research context, this is unsurprising. In all five focus groups there were many instances where some participants had important information that others did not. For example, some participants were hearing for the first time about the 'tourism tax' that had been introduced and already being enforced. A Bueabased focus group participant summed it thus: "The only contact I have with the government is when they come to collect tax. The ministry [Tourism and Leisure] makes new laws but we are not informed even though I think that part of their job apart from enforcing legislation is to sensitize, educate and support us" FG3 P5. While this information deficiency is unsurprising (World Bank, 2008), the focus group participants in urban regions (Douala and Yaoundé) were able to list more of these than the participants in semi-urban regions (Bamenda, Buea and Victoria). Similarly, participants with registered companies had access to more information than those with informal businesses.

The next set of barriers include gender discrimination (2.8), being a woman (3), being less supported in society than men (2.8), and combining household and business tasks (2.8). This result seems to be consistent with established evidence that legislation and some cultures and traditions of Cameroon increasingly recognize men and women as equals (Stevenson \& St-Onge, 2011; World Bank, 2008). As observed during the fieldwork this can be attributed to the fact that the study participants, both men and women were people with experience in dealing with gender relationships. Even some participants in semi-urban regions gave examples of support from their immediate family, for example, as a "housewife" and dependent on a husband in a male-dominated society. For them, dependence on their husbands is crucial in helping to create a STF (e.g. providing start-up capital, advice and giving the wife a chance to run a business on a part-time basis). The men shared this view, and explained instances in which men have supported their wives as this complemented household income. Most of the participants noted that because of their newly acquired independence as professionals and income earners, "men now treat women such as myself with some respect. They no longer treat us with scorn and disdain as they used to do in the past." (FG 4, P9).

Accounts of social transformation of 'others' were discussed along the lines of direct support to employees. For example, the participants explained how the low pay in the sector discouraged people from affluent backgrounds. Consequently, the majority of their staff were girls who come from very poor homes, are poorly educated and are in need of help and support. The following quotation vividly captures this social transformation of young girls:

I have been in this business [Décor \& Events Management] for 11 years and I have trained many girls [as apprentices] who now have their own small decor and event management outfits. Cur- 
rently I have eleven trainees. Parents come to me begging me to train and employ their children as if this is a job for illiterates. You end up teaching them everything from sales to customer service and even how to manage the money you give to them as salaries ... pay their rents, advise them how to leave a healthy life (FG 2, P3).

Accounts of social transformation of 'others' were also discussed in terms of direct support to local development initiatives and the care economy. Although not the focus of this research, such accounts are related to deeply embedded relationships built on extended families, ethnic traditions and informal associations, all of which impose reciprocal obligations on both women and men (Ngoasong \& Kimbu, 2016). Reciprocal obligations include rotating/accumulated payments, subscriptions and voluntary contributions to associations in exchange for membership benefits such as to access financing and social support. The questionnaire data showed that all the women are members of a combination of church groups, ethnic/village meetings/associations and community development associations. It also emerged in the focus groups that for some women, such financial obligations constitute a large proportion of the income they generate from their STFs. They could therefore be said to contribute to the social transformation that informal sector institutions seek to promote (for illustrative cases see Ngoasong \& Kimbu, 2016). The next section discusses how women identify and serve defined community needs, including additional sign-posting of social transformation and commercial goals as being integral to the women-owned STFs.

\section{Identifying and serving defined community needs}

The focus group data reveals different start-up pathways through which women identify and serve defined community needs around tourism as well as evidence of social transformational and commercial goals. Participants gave accounts of the rationales behind women pursuing "earned incomegenerating opportunities, new revenue streams, or innovative means of creating social wealth" (Zahra et al., 2009, p 529) through their STFs, and how they did it. Making use of six emergent cases, such accounts are analyzed below to reveal the choices and pathways to social entrepreneurial activities that women social entrepreneurs take, how they overcome existing barriers to female participation in tourism, and the marginalized and underprivileged persons/communities and destination visitors (domestic and international) that they serve (Ruebottom, 2013). All of these are equally important in the attainment of the goals of promoting tourism development (Desa et al., 2012; Gibson, 2009). The analysis of these cases further articulates the distinctive community needs linked to social transformation and commercial goals, and includes a range of STFs within the sector with different social enterprise status.

First, we consider a woman owner-manager of a not-for-profit car wash that employs only orphans and operates near a popular hotel with easy access to the main tourism sites in the North West Region. The woman described the growing number of orphans around her community as a major societal problem. To overcome the financing challenge, she approached a US-based NGO and secured an initial grant, training and cleaning chemicals/equipment. She also chose to register the enterprise as an NGO. By targeting the needs of visitors, her STF directly complements the functioning of the tourism supply chain (Trinh, Ryan, \& Cave, 2014). She explained that "many visitors come and clean their cars just because of me [a woman] and the children [orphans]. Many later send books, foodstuffs and provisions to the orphanage. This brings in a lot of income which we use to run the orphanage" (FG2, P4). She can be described as a social bricoleur in terms of "making do by providing a new service where none existed beforehand” (Di Domenico et al., 2010, p. 691). Other focus group participants were asked about their views on such an orphanage. A consensus view emerged around how the woman's persistence, the employment and income support to orphans and the continued survival of the car wash were evidence of the social transformative role of women as social entrepreneurs.

The second case is very similar in terms of intent, but illustrates a woman social entrepreneur who deliberately redistributes part of her profits to a marginalized group that is not directly associated with her STF. She created a restaurant following 12 years working in a hotel in Bamenda. Noticing that many visitors found the food being sold in the hotel as being neither health-conscious nor offering value for money, she saw an opportunity to create a restaurant with the primary objective of satisfying 
the food and hospitality needs of visitors. She explained that "visitors remember this restaurant for the food, the cleanliness and the politeness to customers" (FG2, P7). Although the restaurant is operated as a commercial enterprise and registered as a limited company, she describes how the needs of marginalized persons are at the core of her mission:

...With some of the profits from the restaurant, I formed a widows' association five years ago where I give out small low interest loans to needy members and encourage them to start small businesses. Some of them are farmers and I buy most of my fresh produce from them for my restaurant. Widows suffer a lot in our society and as I have the means I feel that I need to support them (FG2, P7).

A third case is a tour operating business in Buea, South West Region. Although registered as a limited company it combines a not-for-profit and a for-profit motive into a single business strategy (Ruebottom, 2013). Even though it is owned by a man, it was represented in the focus group by its operations manager, who is a woman. She explained that "our recruitment process prioritizes women and we have made it our duty to provide them with the necessary training and skills upon employment" (FG1, P1). This is an example of a conscious transformational goal. The focus group participants shared the view that appointing women as managers in a community where there are very few women managers, while being transformative in its own rights, can be commercially viable. For example, the business is able to attract destination visitors and donors who buy in to STFs that have development and empowerment goals. In an informal discussion after the focus group, the owner explained that the reason for sending a woman was to promote an independent view of the goals of his STF.

The fourth case typifies the few respondents who gave a high score for dissatisfaction with their current job as one motivation for creating a STF. Here the views of the participants were consistent with established claims about low pay for the many women who work as housekeepers in hotels/hostels which creates a feeling of marginalization and discrimination (UNWTO, 2011). The case relates to a woman who spotted an opportunity to create an arts and craft shop targeting missionaries and tourists that were visiting a Centre where she previously worked as a receptionist. Growing up in a rural village as a woman, spending time at home doing housework with her mother played a crucial role in generating her initial business ideas. As an adult she got married and moved to Douala (urban) and the husband helped her to secure a job in a large hostel where tourists lodge. This combination of employment and coming into regular contact with tourists enabled her to spot and pursue a market opportunity for creating a STF. As a social bricoleur (Zahra et al., 2009) she can be described as "seizing opportunity for the market-changing innovation of a social purpose" (Luke \& Chu, 2013, p. 765). She vividly described her transformative role and the community needs she serves as follows:

Visitors kept asking for quality handicrafts. This let me to start think about how to open a crafts shop. Because most tourist come in from Douala [main international airport and transit] they buy from us even before starting their travelling to other parts of the country.... I use my business to help the poor. Right now I'm training three young girls [apprentices] how to weave these slippers. In future they can weave slippers and supply to the shop and earn money (FG3, P1).

In the above case the defined community need is the quality of arts and craft as complementary to tourists' needs, and the training she provides to the young girls. The entrepreneur satisfies the tourists' desire to not only acquire something authentic and beautiful but something which is functional during their holidays (Trinh et al., 2014). Although the woman discovered a market opportunity, financial and social support from her husband (Desa et al., 2012) played a major role in her being able to pursue the opportunity, such as actively searching for job opportunities, providing start-up capital and exposure to networks for marketing and sales. In FG 1 and FG5, the men confirmed their role in supporting women, either as wives (where the initial aim is to supplement household income) or as family members (extended family obligations/commitment).

The fifth case concerns a woman who owns a restaurant and catering service in Douala which targets events such as weddings, birth and memorial ceremonies organized by Cameroonians in the diaspora and locals who organize events for which visitors outside Douala are invited. Registered as a limited company, the main community served are diaspora tourists coming home for heritage tourism in the form of organized traditional/cultural and contemporary events (Cave \& Koloto, 2015). 
When I eventually got married and came to Douala to live with my husband, I was always being asked [by my husband or husband's friends] to help cook for a group of people or for some friends who were visiting. We realized that we could instead turn that gesture into a business which will bring financial income. Since then people who organize events that includes visitors coming from abroad and need catering have been our major customers (FG3, P5).

During the fieldwork we observed that renowned hotels provide food at very high prices and many smaller hotels do not run a restaurant section. In three hotels that we lodged in during our fieldwork, the hotel managers explained that hotels do not sell food because of volatile and uncertain visitor numbers, which make it costly to employ kitchen staff who may spend whole days doing nothing. This means that visitors who cannot pay high food prices in large hotels and those who lodge in smaller hotels become important communities in need that are best served by social entrepreneurs such as that illustrated by the fifth case. As the woman-owner manager discussed above explained, with increased success and a growing number of visitors using her service, it has expanded significantly over the past 13 years.

Compared to the formal (state regulated) STFs discussed above, informal enterprises also operate in the tourism sector despite being unregulated by government authorities (see Ngoasong \& Kimbu, 2016). The sixth case typifies the experiences of women whose choices are limited to the informal sector. It concerns a woman participant who specialized in providing catering services to visitors who needed them at very short notice and at affordable prices. Such opportunities enable some women to manage their homes as housewives while raising additional income to fulfill financial obligations beyond their own and immediate family needs. She described her experience vividly as follows:

When a person living in another region or abroad [Cameroonian diaspora] is coming here to organize a wedding or funerals and they require someone local to organize cooking and catering for guests at short notice, they come to me. I prepare everything from my home - food, spoons, and dishes.... We have to bargain and agree a price. This way I can be a housewife and business woman and can pay my financial contributions [to tribal and community associations] without depending on my husband (FG2, P9).

The participants explained that there are a high number of weddings, death and birth ceremonies in Cameroon, which makes the type of catering services offered by FG2, P9 above very attractive, and most providers of such services are women. It is traditional for many people in Cameroon, when they die, to be buried in the region of their ethnic origins (Tamba, 2009). The same applies to traditional weddings where every man must travel with a family delegation to the hometown of his prospective wife to perform traditional wedding rites. Where such a person is a middle or high income earner, there is a preference for higher quality and customized catering services. This is another example of diaspora tourists (Cave \& Koloto, 2015), that is Cameroonians abroad returning home for events.

Taken together, the women social entrepreneurs in the above six cases can be described as social bricoleurs because their STFs are small in scale and local in scope, they are motivated and use whatever expertise and resources are available to address particular community needs (Zahra et al., 2009) around tourism. However, the participants pointed out that limited (financial) resources and expertise limits the size of their businesses and ability to expand. This makes many women to prefer part-time, smaller scale STFs.

\section{Discussion and conclusion}

This article complements tourism social science research debating the tourism development impacts of women as owner-managers of small tourism firms (STFs). Existing research argues that the creation and management of STFs by women, especially those in emerging destinations (Desa et al., 2012), provides women with economic and social independence (Cone, 1995), with the potential for wider development impacts, such as through income generation and job creation (Amine \& Staub, 2009). To understand the nature of this self-identity and the associated development impacts, this article focuses on the social entrepreneurial behavior of individual women within their local context 
(Welter, 2011), defined in terms of the tourism sector and the institutional contexts respectively. Accordingly, the article makes two significant contributions to existing literature.

Firstly, by applying the theoretical lens of social entrepreneurship literature (Ruebottom, 2013; Zahra et al., 2009), the article uncovers the critical role of women owner-managers of STFs as social entrepreneurs capable of promoting local development around tourism. Based on our findings we contribute to the literature debating the role of women in tourism (Acharya \& Halpenny, 2014; Duffy et al., 2015; Moswete \& Lacey, 2015), by developing a framework (Fig. 2) depicting women as social entrepreneurs who simultaneously combine social transformational and commercial goals while serving the needs of defined tourism communities. These ideal determinants of a social entrepreneur are supported by associated sub-determinants that emerged from our empirical analysis. By analyzing the experiences of women owner/managers of STFs in Cameroon, an emerging tourism destination, the findings demonstrate that women and the STFs they own-manage typify social bricoleurs and/or social constructionists because they act on locally discovered opportunities with locally available resources to create STFs that are small in scale, yet provide improvised solutions to small-scaled local social problems (Di Domenico et al., 2010; Zahra et al., 2009).

As Fig. 2 suggests, social transformation of the 'self' takes the form of transitioning from 'traditional' roles of housewives to owner-managers of STFs in a male-dominated setting, while transformation of 'others' (e.g. orphans, widows, young girls) occurs through employment, training and income redistribution. The commercial goals they pursue are largely limited to generating subsistence income and enabling the women to comply with their care obligations to immediate and extended family members, and to community associations. They therefore support social and economic development around tourism by enabling the poorest and underprivileged persons to develop and grow, while serving the needs of domestic and international arrivals and local residents. The above finding also complements recent tourism research that recognizes the societal value of social entrepreneurs in terms of poverty alleviation, environmental protection (Von der Weppen \& Cochrane, 2012) and changes in the tourism landscape of a destination (Kline et al., 2014). It has provided detailed qualitative evidence of the tourism opportunities that are being identified and exploited by women, the startup pathways and potential scalability of the STFs to realizing social value creation.

Secondly, we give voice to women, an otherwise marginalized group in destinations such as Cameroon, where the local context still favors men when it comes to new business creation (Stevenson and St-Onge, 2011; World Bank, 2008). The findings complement previous research (Cone, 1995; Gentry, 2007; Nikina et al., 2015) by uncovering how as entrepreneurs with embedded social purposes (Austin et al., 2006), women overcome institutional and traditional/ethnic barriers to not only create STFs, but to use these as platforms for achieving economic and social independence, while providing access to

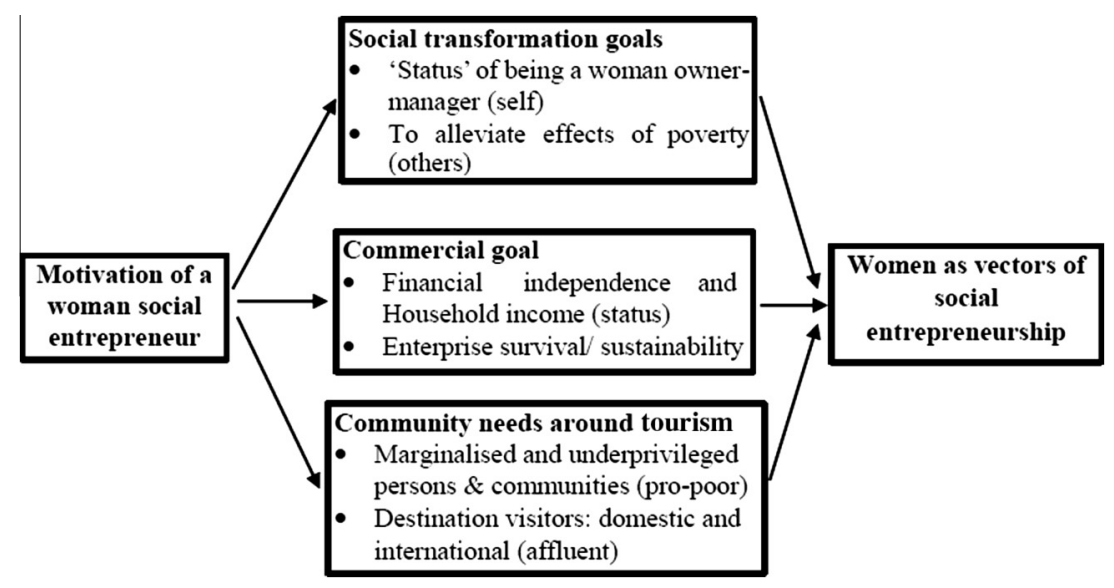

Fig. 2. Understanding women as vectors of social entrepreneurship. 
essential goods and services for tourism and wider communities in need. This is achieved by taking advantage of experiences gained from previous employment, education and/or local networking to access necessary resources for creating and owning STFs. This applies even to those women who maintain their traditional roles as housewives, but who either developed childhood passions for entrepreneurial ideas or are forced into entrepreneurship out of necessity to supplement household income (Desa et al., 2012).

The above findings have practical and policy implications for supporting women to overcome existing barriers to identifying and pursuing social entrepreneurial opportunities (Amine \& Staub, 2009) in ways that enhance local development around tourism. The information sharing and knowledge exchange in focus groups clarified a number of myths that participants had about the significance of women as owner-managers of STFs. The awareness that national legislation on enterprise creation/ownership treated men and women equally was reassuring to those women who operated in the informal sector because of a feeling of gender discrimination. The realization that men can be supportive to women (e.g. in helping to secure financing) even where male-dominated ethnic/traditional practices provide limited incentives to women ownership of assets can also serve as incentives to future women entrepreneurs. Given that most women-owned STFs operate in the informal sector (Derera et al., 2014), government policy incorporating informal STFs into the formal (stateregulated) sector to promote tourism development (Ngoasong \& Kimbu, 2016) could prioritize the needs of women-owned STFs. This includes education and professional skills development, channels for direct marketing of women-owned STFs to destinations (e. g. resorts and national parks) where they are often excluded (Harrison, 2008), inclusion in networks that engage diasporas seen as major heritage and events tourism visitors (Cave \& Koloto, 2015).

By adopting purposive sampling, this article is limited to those cases of women who successfully overcome existing barriers within formal and informal settings to access opportunities and resources (Amine \& Staub, 2009; Datta \& Gailey, 2012; Huysentruyt, 2014) to create and operate STFs. By ensuring data checking, validity and reliability, our methods and findings could be applicable to other destinations (Bernard, 2012; Decrop, 2004). However, our aim was not to draw generalizable conclusions. To increase the generalizability of our findings beyond the participants and cases studied, future qualitative research can either repeat our study with a nonprobability sample or use a probability sample (Bernard, 2012), including in-depth follow-up interviews with individual study participants (Duffy et al., 2015). Secondly, our findings do not imply that simply being a women owner-manager of a STF guarantees systematic transformation and development impacts that can address tourism enclaves and structural inequality (Harrison, 2008). Quantitative studies based on indicators developed using Fig. 1 can usefully clarify the micro-level mechanisms and processes underlying societal level relationships involving women and the magnitude of the development impacts of women social entrepreneurs.

\section{Acknowledgements}

We thank the Sir John Cass Foundation who through the British Academy/Leverhulme Trust funded this research. Our gratitude also goes to the participants in Cameroon who participated in the focus groups, and the research assistants who were instrumental for recruiting the pool of potential entrepreneurs from which the FG participants were eventually selected as well as managing the logistics of the fieldwork.

\section{References}

Acharya, B. P., \& Halpenny, E. A. (2014). Homestays as an alternative tourism product for sustainable community development: A case study of women-managed tourism product in rural Nepal. Tourism Planning \& Development, 10(4), 367-387.

Akehurst, G., Simarro, E., \& Mas-Tur, A. (2012). Women entrepreneurship in small service firms: Motivations, barriers and performance. The Service Industries Journal, 32(15), 2489-2505.

Austin, J. E., Stevenson, H., \& Wei-Skillern, J. (2006). Social and commercial entrepreneurship: Same, different, or both?'. Entrepreneurship Theory and Practice, 30(1), 1-22.

Amine, L. S., \& Staub, K. M. (2009). Women entrepreneurs in sub-Saharan Africa: An institutional theory analysis from a social marketing point of view. Entrepreneurship E Regional Development, 21(2), 183-211. 
Baker, T., \& Nelson, R. E. (2005). Creating something from nothing: Resource construction through entrepreneurial bricolage. Administrative Science Quarterly, 50(3), 329-366.

Bernard, H. R. (2012). Social research methods: Qualitative and quantitative approaches (2nd ed.). Thousand Oaks, CA: Sage (Part 4).

Bruton, G., Khavul, S., \& Chavez, H. (2011). Microlending in emerging economies: Building a new line of inquiry from the ground up. Journal of International Business Studies, 42(5), 718-739.

Buzinde, C. N., Kalavar, J. M., Kohli, N., \& Manuel-Navarrete, D. (2014). Emic understandings of Kumbh Mela pilgrimage experiences. Annals of Tourism Research, 49, 1-18.

Cave, J. (2005). Conceptualising 'Otherness' as a management framework for tourism enterprise. In C. Ryan \& M. Aicken (Eds.), Indigenous tourism - The commodification and management of culture (pp. 315-341). Oxford: Pergamon.

Cave, J., \& Koloto, A. (2015). Short-term visits and Tongan livelihoods: Transnational exchange and enterprise. Population, Space and Place, 21(7), 669-688.

Cone, C. A. (1995). Crafting selves: The lives of two Mayan women. Annals of Tourism Research, 22(2), 314-327.

Christoph, G., Laeis, M., \& Lemke, S. (2016). Social entrepreneurship in tourism: Applying sustainable livelihoods approaches. International Journal of Contemporary Hospitality Management, 28(6), 1076-1093.

Datta, P. B., \& Gailey, R. (2012). Empowering women through social entrepreneurship: Case study of a women's cooperative in India. Entrepreneurship Theory and Practice, 36(3), 569-587.

Decrop, A. (2004). Trustworthiness in qualitative tourism research. In J. Phillimore \& L. Goodson (Eds.), Qualitative research in tourism: Ontologies, epistemologies and methodologies (pp. 156-169). London: Routledge.

Derera, E., Chitakunye, P., \& O'Neill, C. (2014). The impact of gender on start-up capital: A case of women entrepreneurs in South Africa. The Journal of Entrepreneurship, 23(1), 95-114.

Desa, G., Johnson, C., \& Ergul, M. (2012). Hospitably social or socially sustainable? An examination of social entrepreneurship within the hospitality industry. Eurochrie Conference, October 2012, Lausanne Switzerland.

Desa, G. (2012). Resource mobilization in international social entrepreneurship: Bricolage as a mechanism of institutional transformation. Entrepreneurship Theory and Practice, 36(4), 727-751.

Di Domenico, M., Haugh, H., \& Tracey, P. (2010). Social bricolage: Theorizing social value creation in social enterprises. Entrepreneurship Theory and Practice, 34(4), 681-703.

Duffy, L. N., Kline, C. S., Mowatt, R. A., \& Chancellor, H. C. (2015). Women in tourism: Shifting gender ideology in the DR. Annals of Tourism Research, 52, 72-86.

Epo, B. N. (2012). Implications of access to microcredit and social capital for female entrepreneurship in Cameroon. ICBE-RF Research Report No. 39/12.

Gibson, C. (2009). Geographies of tourism: Critical research on capitalism and local livelihoods. Progress in Human Geography, 33 (4), 527-534.

Harrison, D. (2008). Pro-poor tourism: A critique. Third World Quarterly, 29(5), 851-868.

Huysentruyt, M. (2014). Women's social entrepreneurship and innovation. OECD Local Economic and Employment Development (LEED) Working Papers, 2014/01, OECD.

Gentry, K. M. (2007). Belizean women and tourism work: Opportunity or impediment? Annals of Tourism Research, 34(2), $477-496$.

Kimbu, A. N., \& Ngoasong, M. Z. (2013). Centralized decentralization of tourism development: A network perspective. Annals of Tourism Research, 40, 235-259.

Kline, C., Shah, N., \& Rubright, H. (2014). Applying the positive theory of social entrepreneurship to understand food entrepreneurs and their operations. Tourism Planning E Development, 11(3), 330-342.

Kwaramba, H. M., Lovetta, J. C., Louwb, L., \& Chipumuroc, J. (2012). Emotional confidence levels and success of tourism development for poverty reduction: The South African Kwam-Makana home-stay project. Tourism Management, 33(4), 885-894.

Luke, B., \& Chu, V. (2013). Social enterprise versus social entrepreneurship: An examination of the 'why' and 'how' in pursuing social change. International Small Business Journal, 31(7), 764-784.

Mair, J., \& Marti, I. (2006). Social entrepreneurship research: A source of explanation, prediction and delight. Journal of World Business, 41, 36-44.

Mitas, O., Yarnal, C., \& Chick, G. (2012). Jokes build community: Mature tourists' positive emotions. Annals of Tourism Research, 39(4), 1884-1905.

Moswete, N., \& Lacey, G. (2015). Women cannot lead: Empowering women through cultural tourism in Botswana. Journal of Sustainable Tourism, 23(4), 600-617.

Nikina, A., Shelton, L. M., \& LeLoarne, S. (2015). An examination of how husbands, as key stakeholders, impact the success of women entrepreneurs. Journal of Small Business and Enterprise Development, 22(1), 38-62.

Newby, R., Soutar, G., \& Watson, J. (2003). Comparing traditional focus groups with a group support systems (GSS) approach for use in SME research. International Small Business Journal, 21(4), 421-433.

Ngoasong, M. Z., \& Kimbu, A. N. (2016). Informal microfinance institutions and development-led tourism entrepreneurship. Tourism Management, 52, 430-439.

Peeters, L. W. J., \& Ateljevic, I. (2009). Women empowerment entrepreneurship nexus in tourism: Processes of social innovation. In J. Ateljevic \& S. Page (Eds.), Tourism and entrepreneurship: International perspectives (pp. 75-89). Oxford: Butterworth Heinemann.

Ruebottom, T. (2013). The microstructures of rhetorical strategy in social entrepreneurship: Building legitimacy through heroes and villains. Journal of Business Venturing, 28(1), 98-116.

Short, J. C., Moss, T. W., \& Lumpkin, G. T. (2009). Research in social entrepreneurship: Past contributions and future opportunities. Strategic Entrepreneurship Journal, 3(2), 161-194.

Stinchfield, B. T., Nelson, R. E., \& Wood, M. S. (2013). Learning from Levi-Strauss' legacy: Art, craft, engineering, bricolage, and brokerage in entrepreneurship. Entrepreneurship Theory and Practice, 37(4), 889-921.

Stevenson, L. \& St-Onge, A. (2011). Assessment of the environment for the development of women's entrepreneurship in Cameroon, Mali, Nigeria, Rwanda and Senegal. Employment Report No. 15. Geneva: International Labour Organization. 
Tamba, L. M. (2009). Anthropologie des rites funéraires en milieu urbain Camerounais. Paris: L'Harmattan.

Teasdale, S., Lyon, F., \& Baldock, R. (2013). Playing with numbers: A methodological critique of the social enterprise growth myth. Journal of Social Entrepreneurship, 4(2), 113-131.

Trinh, T. T., Ryan, C., \& Cave, J. (2014). Souvenir sellers and perceptions of authenticity: The retailers of H i An, Vietnam. Tourism Management, 45, 275-283.

UNWTO (2011). Global report on women in tourism 2010. Madrid: World Tourism Organization.

UNWTO (2015). Tourism highlights 2015. <http://www.e-unwto.org/doi/pdf/10.18111/9789284416899> (Accessed 16.10.15).

Von der Weppen, J., \& Cochrane, J. (2012). Social enterprises in tourism: An exploratory study of operational models and success factors. Journal of Sustainable Tourism, 20(3), 497-511.

Welter, F. (2011). Contextualizing entrepreneurship: Conceptual challenges and ways forward. Entrepreneurship Theory and Practice, 35(1), 165-184.

World Bank (2008). Doing business: Women in Africa. Washington, DC: World Bank (Report Number 43563).

Zahra, S. A., Gedajlovic, E., Neubaum, D. O., \& Shulman, J. O. (2009). A typology of social entrepreneurs: Motives, search processes and ethical challenges. Journal of Business Venturing, 24, 519-532. 